\title{
General biology and status of Schizothorax richardsonii in Nepal
}

\author{
C.N.R. Yadav', T.K. Ghosh ${ }^{2}$ and B.R. Subba ${ }^{3}$ \\ ${ }^{I}$ Department of Aquaculture, Institute of Agriculture and Animal Science, Tribhuvan University, Rampur, \\ Chitwan, Nepal \\ ${ }^{2}$ University Department of Zoology, T.M. Bhagalpur University, Bhagalpur-812 007, India \\ ${ }^{3}$ Department of Zoology, P.G. Campus, Tribhuvan University, Nepal \\ E-mail: cnryadav@yahoo.com
}

\begin{abstract}
Schizothorax richardsonii, commonly called as spotted snow trout, is a coldwater hillstream fish. It is a delicious fish and is important from sportive and commercial point of view. The hillstream modifications comprise presence of irregular folds of skin acting as papillated suckers on the ventral side of the head, closely situated smaller eyes, small gill openings, reduced air bladder and short-stumpy barbells. Body is spotted, slender and subcylindrical. It is a phytophagous fish with an adaptation in its mouth to scrap algae from the submerged rocks. Spotted snow trout can spawn naturally as well as artificially by stripping. Sexual dimorphism is vivid during breeding season. It starts spawning after second year. Spawning takes place twice in a year- October/November and March/April. Eggs are of sticky nature. Relative and absolute fecundities have been found about 12,000 and 30,000 eggs $/ \mathrm{kg}$ respectively. Optimum temperature for incubation is $15-20^{\circ} \mathrm{C}$ and it takes about 11-18 days for hatching. S. richardsonii has low to moderate vulnerability in Nepal. The population of the fish is decreasing rapidly due to heavy fishing pressure, natural calamity and human disturbances.
\end{abstract}

Key words: Spotted snow trout, hill stream phytophagous fish, Asala

\section{Introduction}

Schizothorax richardsonii (Gray, 1832), commonly known as snow trout and locally called as Asala, is a hillstream fish. Hillstreams differ from other rivers of the plain having steep gradient and thus highly turbulent and shooting hyperoxic water current with shallow and rocky bottom. The fast flowing cold streams of the upper reaches of Nepal are the natural abode of this economically important fish. The hillstream fishes are different from other fishes by virtue of the development of adhesive structures for anchorage, providing support against the torrential water current of the stream and other adaptational modifications in their shape and size, mouth and other associated structures. It is a high valued fish which is famous and preferred for its excellent taste.

Shrestha (1994) reported altogether seven species of genus Schizothorax (Heckel, 1838) from Nepal. They are $S$. sinuatus, $S$. molesworthi, $S$. plagiostomus, $S$. richardsonii, $S$. macrophthalmus, S. nepalensis and S. raraensis. Further, following the revised classification of fishes done by Jayram (1999) the two species of Schizothorax viz., S. molesworthi and S. plagiostomus are merged and considered as the synonyms of S. richardsonii. Schizothoraichthys annandalei is also included under $S$. richardsonii. And all the three species of Schizothorax ( $S$. macrophthalmus, S. raraensis, S. nepalensis) reported from lake Rara, Nepal by Terashima (1984) are transferred to genus Schizothoraichthys. Collectively they are called as snow trout. 
There are altogether 11 snow trouts reported from Nepal under 3 genera - Schizothorax having two species, Schizothoraichthys having eight species and Diptychus with single species.

Genus: Schizothorax (Heckel, 1838)

1. S. richardsonii (Gray, 1832)

2. S. sinuatus (Heckel, 1838)

Genus: Schizothoraichthys (Misra, 1959)

3. S. esocinus (Heckel, 1838)

4. S. curvifrons (Heckel, 1838)

5. S. labiatus (McClelland, 1839)

6. S. macrophthalmus (Terashima, 1984)

7. S. nepalensis (Terashima, 1984)

8. S. raraensis (Terashima, 1984)

9. S. niger (Heckel, 1838)

10. S. progastus (McCelland, 1839)

Genus: Diptychus (Steindachner, 1866)

11. D. maculatus (Steindachner, 1866)

Systematic position

Asala or S. richardsonii looks like a trout so it is also called as snow trout but it does not belong to the trout group. The systematic position of $S$. richardsonii is given below after Nelson (1994):

Phylum - Chordata

Subphylum - Vertebrata

Superclass - Gnathostomata

Grade - Pisces

Subgrade - Teleostomi

Class - Osteichthyes

Subclass - Actinopterygii

Infraclass - Teleostei

Division - Euteleostei

Superorder - Ostariophysi

Series - Otophysi

Order - Cypriniformes

Suborder - Cyprinoidei

Family - Cyprinidae

Subfamily - Schizothoracin(ae)/i (Oreininae)

Genus - Schizothorax (Heckel, 1838)

Species - S. richardsonii (Gray, 1832)

Common name

Asala is known by different names like Dhumke Asala, Soal, Buchche Asala, Spotted snow trout and so on in different parts of Nepal.

\section{Distribution}

The subfamily Schizothoracinae (family Cyprinidae), which includes snow trout and several other genera, is found in the Himalayan and sub-Himalayan regions of the Indo-Chinese 
subcontinent (Sikkim, Tibet, Bhutan, Nepal and Pakistan), Afghanistan, central Asia, Kazakhstan, China and Myanmar, hence it is indigenous for the region. There are 28 species of snow trout in the Himalayan and sub-Himalayan regions including China and Pakistan (Sharma, 1989). Snow trout is found in India in cold waters from Jammu and Kashmir to Nainital (Sundar \& Bhagat, 1979). Jhingran (1982) reported its distribution from Assam and eastern Himalayas through Bhutan and Sikkim at an altitude of 1180-3,000 m. In Nepal, it has been reported from rivers and lakes/reservoirs at an altitude of 300-3,323 $\mathrm{m}$ and between $8-22^{\circ} \mathrm{C}$ (Shrestha, 1981).

\section{Habit and habitat}

Snow trout (Schizothorax sps. and Schizothoraichthys sps.) is the dominant fish in the cold waters of hilly region (Rajbanshi, 2002). S. richardsonii is an inhabitant of higher altitude, cold and hyperoxic waters of the hillstreams of Nepal and adjacent countries. Maximum size reported by Rajbanshi (1971) of $S$. richardsonii is $48 \mathrm{~cm}(1.5 \mathrm{~kg})$ but up to $5.0 \mathrm{~kg}$ of this fish has been reported by the fishermen (Rai et al., 2002). Talwar and Jhingran (1991) reported up to $60 \mathrm{~cm}$ of its total length in India. It is a riverine and short migratory potamodromous fish which migrates for feeding and breeding purposes. It migrates from headwaters to lower altitude i.e. downstreams in winter to cope with the steep fall in temperature and in search of food (the phenomenon is called as Udhounli in Nepali) and to upstreams in summer (called as Ubhounli) seeking favourable temperature, water current and breeding ground for spawning.

Due to biological condition of the hill streams, Schizothorax sps. develop adhesive organ for adhesion in the fast flowing water. The anchorage devices in hillstream fishes are either in the form of true sucker, adhesive organs with ridges and grooves, or with irregular folds (Ojha, 2002). In S. richardsonii irregular folds of skin act as papillated sucker and are discernible on the ventral side of the head. Such irregular folds and ridges facilitate the creation of partial vacuum on the ventral side of the body which helps the fish to escape from sweeping away with the torrential water current. During the winter, when water is at its lowest level and is highly transparent, they accumulate in pools. The phenomenon is called as 'Cuur' in local term. Schizothoracines chase intruders to defend the available shelter and limited food resource.

\section{Characteristic features}

Asala/snow trout is the common name used for Genera Schizothorax and Schizothoraichthys in Nepal. Genus Schizothorax can be distinguished from Genus Schizothoraichthys having a blunt snout and a papillated suctorial lip. Due to blunt snout genus Schizothorax is locally called as 'Buchche Asala'. The hillstream modifications noticed in this fish are flattening of head and thus the eyes are shifted more towards the dorsal side and remain close together. The eyes are small in size due to intensive light in hillstreams. Due to bottom dwelling nature, thick scales are lacking on the ventral surface of the body. Other structural modifications are adhesive apparatus, small gill openings, reduced air bladder, and short and stumpy barbels (Shrestha, 1994).

Body is spotted, slender, elongated, sub-cylindrical and strong to resist the torrential water current of the hillstreams. Abdomen is rounded. Head is large and dorsoventrally flattened. Snout is blunt. Mouth is inferior and transverse. It is more or less crescentic or semi-circular in shape with strong jaws (Fig. 1). Lips are thick and fleshy. Lower lip is with a free posterior edge forming a papillated sucker. Two pairs of short and stumpy barbels are present, one each rostral and maxillary. Lower jaw has a hard and horny cartilaginous covering inside. Dorsal fin is 
inserted slightly ahead of pelvics and slightly nearer to root of caudal fin than tip of snout. It is with 10 or 11 rays and with a spine which may be articulated, smooth or serrated. Anal fin is short and with 7 or 8 rays. Caudal fin is forked. Vent and anal fin are lodged in a sheath covered by an enlarged row of scales. The body is covered with minute scales, grayish black on dorsal side and silvery on the belly and the sides. Lateral line is complete with 94-110 scales. Air bladder is free and tripartite.

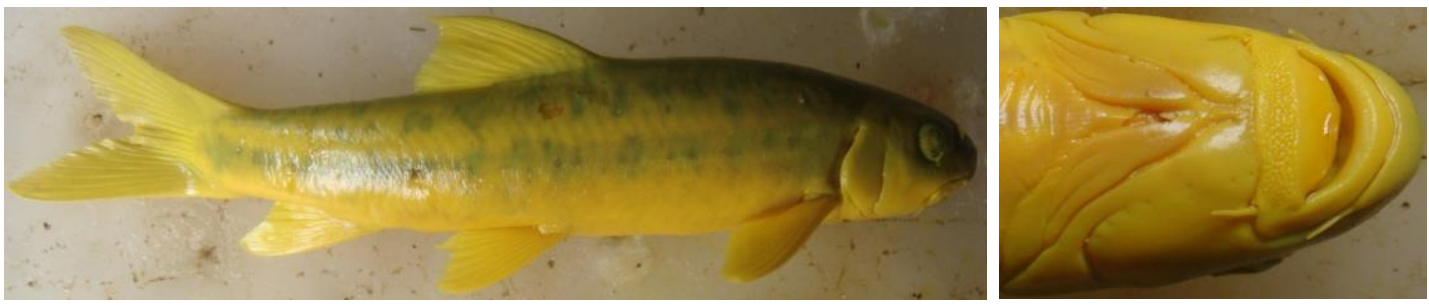

Figure 1. S. richardsonii, lateral and ventral view showing adhesive structure and inferior cum crescentic mouth

Key to genus Schizothorax (Heckel, 1838): Barbels present; body completely covered with scales; lower lip modified into a papillated sucker on the chin; mouth much less crescentic and inferior (Talwar \& Jhingran, 1991; Jayram, 1999).

Key to species $S$. richardsonii (Gray, 1832): Body depth 4.5 to 4.7 times in standard length; barbels smaller than eye diameter; snout length 2.02 to 2.4 times in head length; dorsal fin inserted nearer to caudal base than tip of snout (Talwar \& Jhingran, 1991; Jayram, 1999).

$$
\begin{gathered}
\text { Fin formula } \\
\mathrm{B}_{\mathrm{III}} ; \mathrm{D}_{\mathrm{II}-\mathrm{III} / 8}, \mathrm{P}_{\mathrm{I} / 15-16}, \mathrm{~V}_{\mathrm{I} / 9-10}, \mathrm{~A}_{\mathrm{II}-\mathrm{III} / 5}, \mathrm{C}_{19} \text {, L.1.94-110, Bar. } 2 \text { pairs. }
\end{gathered}
$$

\section{Feeding habit}

S. richardsonii is a phytophagous fish with an adaptation in its mouth to scrap attached algae from the surface of submerged rocks and stones. The mouth is crescentic or semi-circular in shape with strong horny jaws well adapted for hillstream condition. The feeding habits have been studied by several workers (Terashima, 1984; Sharma, 1989; Rai et al., 2002). It is a good browser and feeds on attached diatoms, green and blue-green algae including Spirogyra, Ulothrix, Oedogonium, etc. as well as on the benthic insects like mayflies, caddis flies, ephemeropterans, etc., and their larvae, and detritus such as rotten leaves, decayed organic matters, etc. Fry feed on larvae of chironomids and caddis flies as well as microscopic algae.

\section{Reproductive biology}

Asala can spawn naturally as well as artificially by stripping. Having high food and economic values, the demand of the fish increases gradually and its artificial propagation has been taken into account using ovaprim (Agarwal et al., 2007) to meet the demand. S. richardsonii starts spawning at the age of two years attaining the length of $18-24 \mathrm{~cm}$. Sexual dimorphism is vivid in this fish especially during breeding season (Rajbanshi, 1971; Terashima, 1984). Mature males have rough snout due to presence of well developed nuptial tubercles whereas females have smooth one. Mature males develop faint yellow colour of the body and reddish colour of the fins during the breeding season which distinguish them from females. Female spawns twice in a year- September/October and March/ April (Rai et al., 2002). Clear water, stony bottom of 
stream having creeks and crevices composed of fine pebbles and gravels, and water flow of 2.8$4.0 \mathrm{~m} / \mathrm{sec}, \mathrm{pH} 7.5$ and dissolve oxygen concentration of $10-15 \mathrm{mg} / \mathrm{l}$ form favourable spawning conditions in the natural environment. Males produce sperms throughout the year. Eggs are of sticky nature and attached to the rocky substrate. Relative fecundity has been found about 12000 eggs $/ \mathrm{kg}$. Absolute fecundity reaches up to 30,000. Optimum temperature for incubation is $15-20^{\circ} \mathrm{C}$ and it takes about $11-18$ days for hatching. In nature, the population doubling time of $S$. richardsonii is 1.4-4.4 years (Talwar \& Jhingran, 1991).

\section{Angling}

Coldwater fish are considered tastier than other fishes and thus fetch a good market price. $S$. richardsonii is considered as an exceptionally good quality food. It is well known to the anglers as its angling process is exciting. It is easy to land into net being smaller in size. For catching the snow trout, the local people of Nepal have created a simple loop made of monofilament thread and the fishing method is called as 'looping of Asala' (Rajbanshi, 1976).

\section{Status in Nepal}

Deterioration of catchment soil by inappropriate agricultural practices and deforestation, and pollution are reducing the water quality, harming the coldwater fish stocks (Petr, 2002). While collecting S. richardsonii from Puwa Khola of Ilam District for the purpose of study the riverbed was found almost naked i.e. totally devoid of algal matter, due to repeated use of poisonous chemicals for the purpose of fishing. It badly affects not only the fish species but also the aquatic habitat as a whole, which in turn devastates the biodiversity too. Similar findings have been reported by Swar (2002).

S. richardsonii has undergone low to moderate vulnerability in Nepal (Shrestha, 1995) as well as in India (Talwar \& Jhingran, 1991). S. richardsonii has been declared as a threatened species in Nepal (Shrestha, 1999). If illegal methods of fishing are not checked, the species may face extinction. The population of the fish is decreasing rapidly due to heavy fishing pressure, natural calamities as well as human disturbances such as construction of dams and roads, etc. The deteriorating environment, increased industrial activities with a consequent draining of the effluents in rivers and lakes, construction of hydropower dams without any appropriate and adequate provision for fish migration and indiscriminate killing of fish using illegal fishing methods are considered to be responsible for the depletion of the fish (Rajbanshi, 2002).

Overfishing has become a problem in many coldwater streams and rivers. However, the Government of Nepal has made laws and by-laws to check over- and illegal fishing for protection of aquatic organisms specially whose population is showing a diminishing trend. $S$. richardsonii has been completely banned from fishing during breeding periods, March/April and September/October. Again this fish measuring less than $15 \mathrm{~cm}$ is banned from fishing even in the non breeding months. The violators of the laws should be prosecuted but the enforcement part is not much effective so far.

\section{Acknowledgement}

The University Grants Commission, Nepal is acknowledged for providing partial financial support to carry on fieldwork. 


\section{References}

Agarwal, N.K., B.L. Thaplial \& S.K. Raghuvanshi. 2007. Induced breeding and artificial fertilization of snowtrout, Schizothorax richardsonii through the application of ovaprim. J. Inland Fish. Soc. India. 39(1): 12-19.

Jayram, K.C. 1999. The freshwater fishes of the Indian region. Narendra Publishing House. Delhi, India. 551p.

Jhingran, V.G. 1982. Fish and Fisheries of India. Hindustan Publishing Corporation, India. 727p.

Nelson, J.S. 1994. Fishes of the world. $3^{\text {rd }}$ edition. John Wiley \& Sons, Inc. New York. 600p.

Ojha, J. 2002. Biology of hill stream fishes. Narendra Publishing House. Delhi, India. 177p.

Petr, T. 2002. Coldwater fish and fisheries in countries of the high mountain arc of Asia (Hindu Kush-Pamir-Karakoram-Himalayas). A review. FAO Fisheries Technical Paper No. 431, FAO, Rome. pp. 1-38.

Rai, A.K., B.R. Pradhan \& S.R. Basnet. 2002. Present status of snow trout in Nepal. FAO Fisheries Technical Paper No. 431, FAO, Rome. pp. 213-220.

Rajbanshi, K.G. 1971. Sexual dimorphism in "Snow-trout" Schizothorax sp. (Asla). Nep. J. Sc. 1(3, 4): $25-27$.

Rajbanshi, K.G. 1976. Looping of "Snow trout"- Asla. J. Science. Kathmandu 6(1): 59-64.

Rajbanshi, K.G. 2002. Zoogeographical distribution and the status of coldwater fish in Nepal. FAO Fisheries Technical Paper No. 431, FAO, Rome. pp. 221-246.

Sharma, B.P. 1989. Status of Schizothorax sp. in the Indian-Chinese sub-continent. FAO Fisheries Report No. 405 (suppliment), FAO, Rome. pp. 90-94.

Shrestha, J. 1981. Fishes of Nepal. Curriculum Development Centre (CDC), Tribhuvan University, Kathmandu, Nepal.

Shrestha, J. 1994. Fishes, fishing implements and methods of Nepal. Publ. M.D. Gupta, Lashkar (Gwalior), India. 144p.

Shrestha, J. 1995. Enumeration of the fishes of Nepal. Biodiversity profiles project. His Majesty's Government of Netherlands, Euroconsult, Arnhem, The Netherlands. 150p.

Shrestha, T.K. 1999. Overview on fish. In: Nepal country Report on biological diversit (Shrestha, T.B. Ed.). IUCN, Kathmandu, Nepal. pp. 52-59.

Sunder, S. \& M.J. Bhagat. 1979. A note on the food of Schizothorax plagiostomus (McClelland) in the Chenab drainage of Jammu Province during 1973-74. J. Inland Fish. Soc. India. 11(1): 117-118.

Swar, D.B. 2002. The status of coldwater fish and fisheries in Nepal and prospects of their utilization for poverty reduction. FAO Fisheries Technical Paper No. 431, FAO, Rome. pp. 79-96.

Talwar, P.K. \& A.G. Jhingran. 1991. Inland fishes of India and adjacent countries. Volume 1. Oxford \& IBH Publishing Co. Pvt. Ltd. New Delhi, Bombay, Calcutta (India). 541p. 